\title{
STRATEGI PENGEMBANGAN AGRIBISNIS STROBERI PADA CV. BUMI AGRO TECHNOLOGY, JAWA BARAT
}

\section{DEVELOPMENT STRATEGY OF STRAWBERRY AGRIBUSINESS IN CV. BUMI AGRO TECHNOLOGY, WEST JAVA}

\author{
Mikha Gracina Devonian Silaban*, Lucyana Trimo \\ Universitas Padjadjaran, Jl. Raya Bandung Sumedang Km 21 \\ *E-mail: mikhagracina9990@gmail.com \\ (Diterima 10-11-2020; Disetujui 29-12-2020)
}

\begin{abstract}
ABSTRAK
CV. Bumi Agro Technology merupakan perusahaan yang bergerak pada produksi bibit tanaman dan juga buah stroberi yang memiliki reputasi yang baik di Jawa Barat. Akan tetapi, hasil produksi bibit dan buah stroberi CV. Bumi Agro Technology mengalami flukuatif, sehingga dapat dikatakan bahwa agribisnis stroberi di CV. Bumi Agro Technology masih belum dilakukan secara optimal. Oleh sebab itu, CV. Bumi Agro Technology perlu mengembangkan agribisnis stroberi dengan terlebih dahulu mengidentifikasi kekuatan, kelemahan peluang dan ancaman yang dihadapi oleh perusahaan. Penelitian ini bertujuan untuk mengetahui faktor internal dan eksternal pada perusahaan, dan menentukan strategi pengembangan agribisnis stroberi yang tepat untuk mengoptimalkan usahanya. Desain penelitian ini adalah kualitatif, dengan teknik penelitian studi kasus. Metode pengumpulan data yang digunakan adalah wawancara, observasi dan studi literatur. Dalam penentuan strategi pengembangan, terbagi menjadi tiga tahap. Tahap input (input stage) menggunakan matriks IFE dan EFE. Pada tahap pencocokan (matching stage) menggunakan matriks IE dan matriks SWOT. Tahap terakhir adalah tahap pengambilan keputusan (decision stage) digunakan matriks QSPM. Berdasarkan hasil mastriks SWOT diperoleh delapan alternatif strategi yang kemudian dianalisis menggunakan QSPM, sehingga diperoleh urutan prioritas strategi sebagai berikut: (1) Mempertahankan kualitas produk, (2) Menambah kegiatan pelatihan kerja, (3) Meningkatkan promosi, (4) Memperbaiki sistem pembukuan, (5) Menciptakan varietas stroberi baru, (6) Memanfaatkan lahan kosong pada kebun produksi, (7) Mempertahankan dan meningkatkan kualitas pelayanan kepada konsumen, dan (8) Pengembangan kemitraan antara perusahaan dengan konsumen dan petani.
\end{abstract}

Kata kunci: Stroberi, Strategi Pengembangan Agribisnis, Faktor Internal dan Eksternal, SWOT, QSPM

\section{ABSTRACT}

$C V$. Bumi Agro Technology is a company engaged in the production of strawberry's plant seeds and fruis which has a good reputation in West Java. However, the production of strawberry's seeds and fruits in CV. Bumi Agro Technology is fluctuating so it can be said that the strawberry farming is still not being carried out optimally. Therefore, CV. Bumi Agro Technology needs to develop strawberry agribusiness by first identifying the strengths, weaknesses, opportunities and threats faced by the company. This study aims to determine the internal and external factors in the company and obtaine the viable strawberry agribusiness development strategies to optimize its business. The design in this study used a qualitative design with a case study research technique. Data collection methods used such as interview, observation and literature study. In determining the development strategy, it is divided into three stages. The first stage is input stage which uses the IFE and EFE matrix. The matching stage uses IE matrix and SWOT matrix. The last stage is the decision stage using the QSPM matrix. From the results of the SWOT analysis, it was obtained eight alternative strategies which were further analyzed using QSPM with the following priority strategies: 1) Maintaining product quality, (2) Increasing job training, (3) Increasing promotion, 
(4) Improving financial systems, (5) Creating new strawberry varieties, (6) Utilizing empty land in production areas, (7) Maintaining and improving service quality to consumers, and (8) Developing partnerships between companies and consumers and also farmers.

Keywords: Strawberries, Agribusiness Development Strategy, Internal and External Factors, SWOT, QSPM

\section{PENDAHULUAN}

Subsektor hortikultura merupakan salah satu subsektor pertanian yang memiliki potensi bagi perekonomian Indonesia. Kontribusi subsektor hortikultura tersebut tercermin dari indikator ekonomi makro seperti Produk Domestik Bruto (PDB). Berdasarkan data Badan Pusat Statistik (2020), PDB subsektor hortikultura memberi kontribusi terhadap total PDB Sektor Pertanian di tingkat nasional sebesar $16,03 \%$ pada tahun 2019. Berdasarkan data tersebut, dapat dikatakan bahwa subsektor hortikultura porspektif untuk dikembangkan.

Salah satu komoditas subsektor hortikultura yang unggul dan layak untuk dikembangkan adalah stroberi. Hal tersebut ditunjang oleh hasil penelitian Purnomo (2008) mengenai startegi pengembangan agribsinis stroberi, dikatakan bahwa stroberi merupakan salah satu komoditas hortikultura yang mempunyai potensi ekonomi yang tinggi, hal ini dikarenakan stoberi memiliki daya tarik tersendiri yang terletak pada bentuk, rasa dan warna dari buah stroberi sehingga berpengaruh terhadap harga jualnya di pasar yang termasuk kategori tinggi dan menjanjikan dengan melihat peluang bisnis yang ada baik di dalam maupun luar negeri.

Pemasaran stroberi sendiri cakupannya sudah luas mulai dari pemasaran di tingkat lokal seperti ke konsumen untuk konsumsi pribadi maupun ke restoran, hotel, katering bahkan hingga diekspor ke luar negeri.

Jika melihat dengan budidaya stroberi di luar negeri, usahatani atau budidaya tanaman stroberi di Indonesia belum seoptimal seperti di negara lain yang juga merupakan negara penghasil komoditas stroberi seperti Amerika, Jepang dan beberapa negara di Eropa. Hal ini dikarenakan metode dari budidaya stroberi di Indonesia yang belum diterapkan dengan tepat (Budiman dan Saraswati, 2006). 


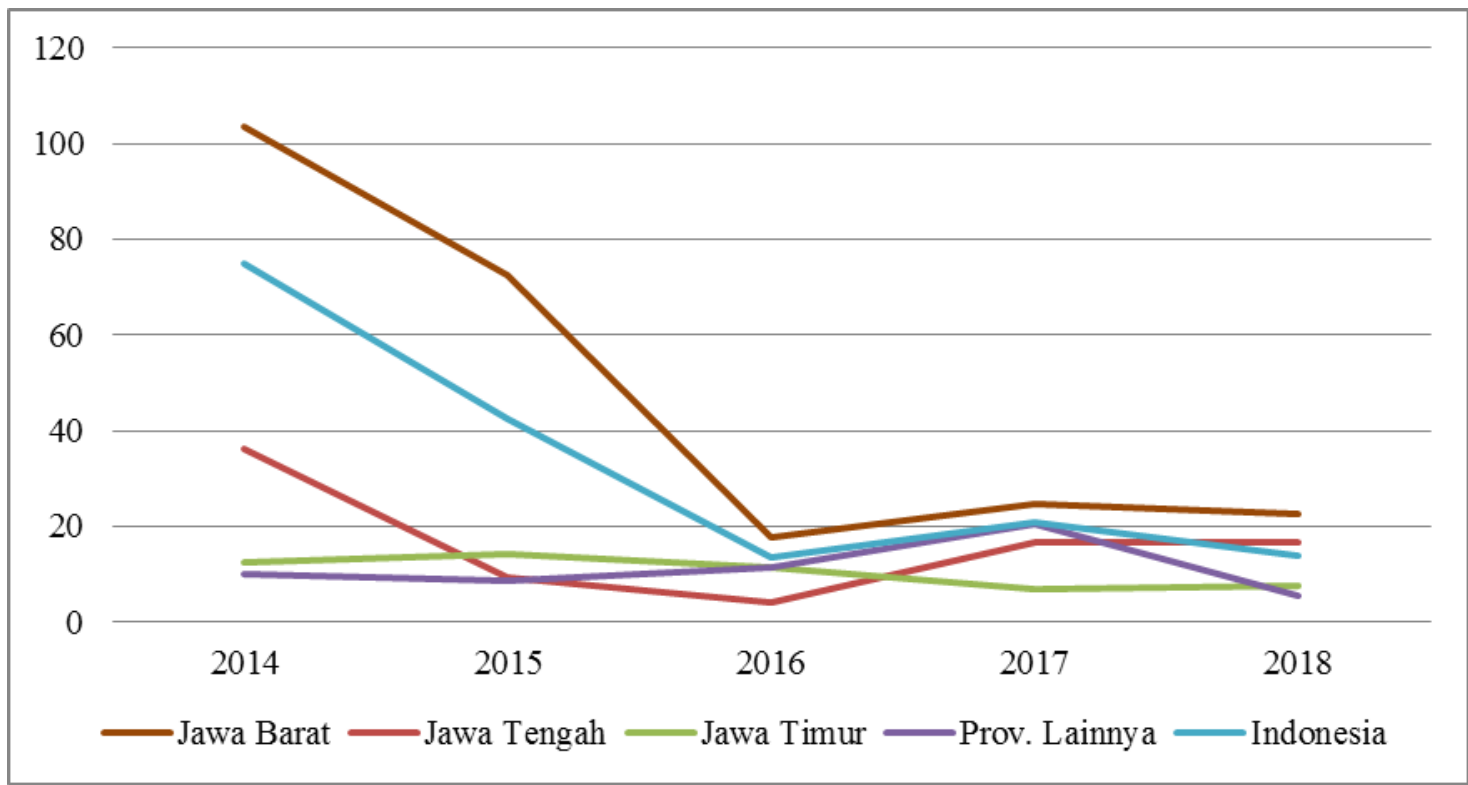

Gambar 1. Produktivitas Stroberi menurut Provinsi Tahun 2014-2018

Sumber: Statistika Tanaman Sayuran dan Buah-Buahan Semusim Indonesia (2017)

Dari Gambar 1 di atas, dapat diketahui bahwa produktivitas stroberi di Indonesia berfluktuasi bahkan cenderung mengalami penurunan dari tahun 20082017. Namun demikian, jika melihat dari sisi produksi hortikulturanya di Indonesia sepanjang tahun 2014 sampai dengan 2018. Pada tahun 2018, Jawa Barat merupakan daerah dengan produksi stroberinya mencapai 6.296 ton yang memberikan kontribusi sebesar 73,32\% terhadap pada total produksi stroberi di tingkat nasional.

Potensi budidaya stroberi yang didukung juga dengan pesatnya pertumbuhan sektor pariwisata di daerah Jawa Barat menjadi salah satu penunjang tingginya pertumbuhan sektor budidaya tanaman stroberi, baik hanya untuk tingkat produksi saja maupun untuk pada tingkat agrowisatanya. Hasil produksi stroberi selain untuk dijual sebagai produk segar, dapat juga dikembangkan dan diberi nilai tambah menjadi berbagai produk olahan sehingga menambah juga pendapatan bagi pelaku agribisnis stroberi lainnya.

Salah satu perusahaan hortikultura di Jawa Barat ialah CV. Bumi Agro Technology. Perusahaan ini merupakan perusahaan yang bergerak pada produksi bibit tanaman dan juga buah stroberi. Perusahaan telah berdiri sejak tahun 2011, akan tetapi baru mulai melakukan kegiatan agribisnis stroberi sejak tahun 2014.

CV. Bumi Agro Technology merupakan perusahaan yang dapat 
menunjukkan kualitas dari agribisnis stroberinya. Hal ini dapat dilihat dari kemampuan CV. Bumi Agro Technology yang masih dapat bertahan ketika pada tahun 2016 terjadi wabah yang menyerang hampir seluruh kebun stroberi di Kabupaten Bandung Barat yang menyebabkan banyak petani stroberi gagal panen serta perusahaan di bidang agribisnis stroberi gulung tikar.

CV. Bumi Agrotechnolgy mampu menunjukkan eksistensinya dengan memproduksi bibit dan buah stroberi yang berkualitas dan tahan terhadap hama penyakit dan organisme penganggu tanaman. Hal tersebut didukung oleh teknologi yang telah diterapkan oleh $\mathrm{CV}$ Bumi Agrotechnology dalam memproduksi bibit dan buah stroberi berkualitas hingga saat ini. Oleh sebab itu, hal ini juga yang menjadi alasan CV. Bumi Agro Technology sebagai perusahaan yang memiliki potensi untuk diteliti lebih lanjut guna pengembangan agribisnis stroberi pada CV. Bumi Agro Technology.

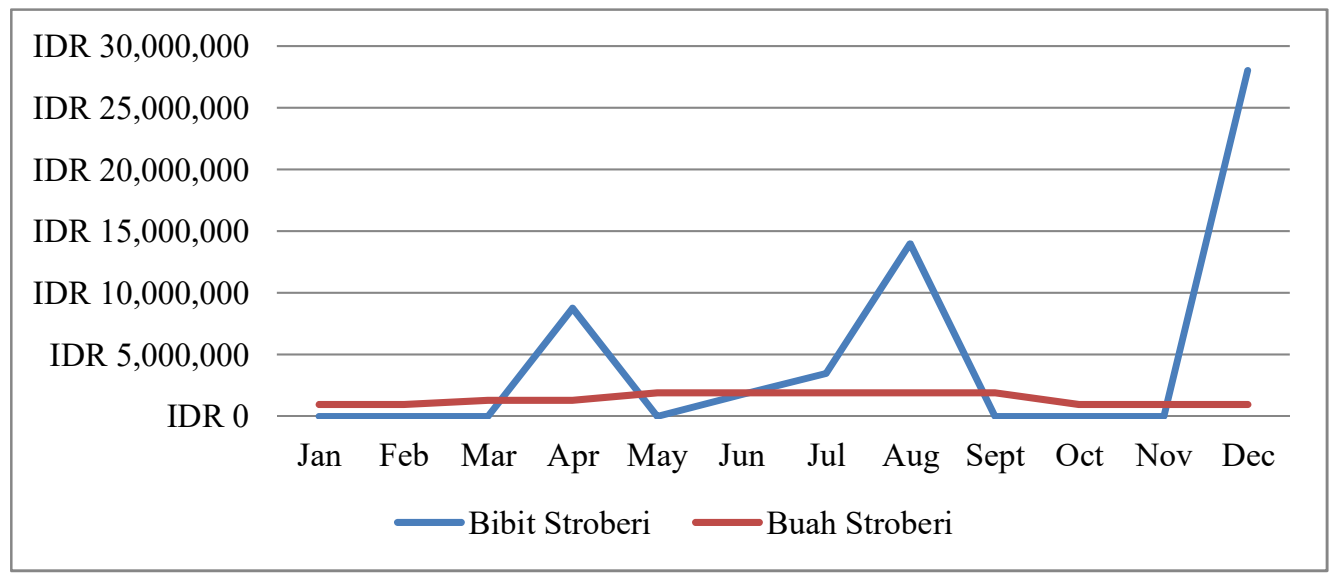

Gambar 2. Perbandingan Penjualan Bibit Tanaman dan Buah Stroberi di CV. Bumi Agro Technology pada Tahun 2019

Sumber: Data Perusahaan CV. Bumi Agro Technology (2018), Diolah oleh peneliti

Dari grafik pada Gambar 4, dapat diketahui perbandingan penjualan bibit tanaman stroberi dan buah stroberi pada CV. Bumi Agro Technology tiap bulan pada tahun 2019 mengalami fluktuasi. Selain itu, apabila dilihat dari segi ekonominya dapat diketahui bahwa penjualan bibit stroberi CV. Bumi Agro
Technology pada tahun 2019 lebih besar penerimaannya, dan tentunya lebih menguntungkan dibandingkan dengan penjualan dari buah stroberi pada $\mathrm{CV}$. Bumi Agro Technology. Hal tersebut menunjukkan bahwa produktivitas buah dan bibit stroberi di perusahaan belum optimal. 
Maka dari itu, hal tersebut menjadi tantangan tersendiri bagi CV. Bumi Agro Technology sebagai salah satu perusahaan yang bergerak di bidang agribisnis stroberi untuk terus mengembangkan usahanya melalui strategi pengembangan yang tepat untuk diimplementasikan bagi perusahaannya dengan terlebih dahulu mengidentifikasi kekuatan, kelemahan peluang dan ancaman yang dihadapi oleh perusahaan agar dapat mengoptimalkan keuntungan.

\section{METODE PENELITIAN}

Desain pada penelitian ini merupakan desain kualitatif. Dalam penelitian kualitatif, data yang diolah merupakan fakta (fact) atau informasi yang diperoleh dari subjek penelitian dan akvitas serta tempat yang menjadi objek penelitiannya (Idrus, 2009). Pemilihan desain kualitatif pada penelitian ini didasarkan pada pertimbangan mengenai perlunya pendekatan individu yang lebih terperinci dan mendalam pada subjek penelitian agar diperoleh data yang valid atau dapat dipercaya kebenarannya.

Subjek penelitian pada penelitian ini yaitu informan yang terdiri atas direktur CV. Bumi Agro Technology, sekretaris dan keuangan, supervisor stroberi di kebun produksi baru Ajak, supervisor stroberi kebun Cisarua, kepala divisi consultant and trading, dan seorang tenaga kerja divisi produksi $\mathrm{CV}$. Bumi Agro Technology sebagai informan kunci, serta seorang dari pihak BPSBPTH (Balai Pengawasan dan Sertifikasi Benih Tanaman Pangan dan Hortikultura), Dinas Pertanian Provinsi Jawa Barat sebagai informan pendukung. Penelitian pada agribisnis stroberi di CV. Bumi Agro Technology ini menggunakan teknik studi kasus. Menurut Moehar Daniel (2003) studi kasus merupakan teknik penelitian yang lebih terarah dan terfokus pada suatu karakter tertentu yang tidak umum. Dalam penelitian ini, peneliti menggunakan teknik studi kasus guna mengetahui kekuatan, kelemahan, peluang dan ancaman pada perusahaan. Berikutnya data yang diperoleh dianalisis secara deskriptif menggunakan matriks IFE, EFE, IE dan matriks SWOT serta QSPM untuk memperoleh berbagai prioritas strategi pengembangan yang tepat bagi agribisnis stroberi di CV. Bumi Agro Technology. 
Matriks Internal Factor Evaluation (IFE)

Menurut David (2009), matriks IFE merupakan matriks untuk mengetahui lingkungan internal yang dimiliki perusahaan guna menentukan faktorfaktor internal yang merupakan kekuatan dan kelemahan yang dimiliki perusahaan.

\section{Matriks External Factor Evaluation (EFE)}

Menurut David (2009), matriks EFE merupakan matriks guna mengetahui dan menentukan faktorfaktor eksternal yang merupakan peluang dan ancaman yang mungkin dihadapi oleh perusahaan melalui identifikasi pada lingkungan eksternalnya.

\section{Matriks Internal External (IE)}

Matriks IE merupakan alat analisis untuk menggabungkan total skor yang telah diperoleh dari matriks IFE dan EFE untuk kemudian mengetahui posisi perusahaan dan berkaitan pada implikasi strategi bagi perusahaan. Adapun strategi tersebut dikelompokkan ke dalam 3 daerah utama yang memiliki implikasi strategi masing-masing yang berbeda, yaitu:

1. Tumbuh dan Kembangkan (Growth and Build)
Implikasi strategi ini berada pada sel

I, II dan IV dimana strategi yang dianjurkan untuk dilakukan ialah strategi intensif dan strategi integrasi.

2. Pelihara dan Pertahankan (Hold and

\section{Maintain)}

Perusahaan yang berada pada posisi Hold and Maintain berada pada sel III, V dan VII. Strategi yang dapat dilakukan untuk perusahaan pada posisi ini adalah strategi penetrasi pasar, strategi pengembangan produk dan optimalisasi produk dan juga pemanfaatkan perkembangan teknologi yang sudah ada pada perusahaan.

3. Tuai atau Divestasi (Harvest or Divest)

Implikasi posisi untuk Tuai dan Divestasi adalah jika skor total perusahaan menunjukkan posisi pada sel VI, VIII, dan IX. Strategi yang disarankan untuk dilakukan adalah strategi divestasi.

\section{Matriks SWOT}

Menurut David (2009), matriks SWOT merupakan suatu alat yang digunakan untuk menyusun faktor-faktor strategis. Matriks ini memetakan bagaimana peluang dan ancaman eksternal yang mungkin timbul dapat 
dihadapi dengan kekuatan dan kelemahan internal.

Rangkuti (2001) menyatakan, bahwa matriks SWOT adalah alat untuk menyusun strategi dalam rangka memenangkan persaingan bisnis dengan konsep cooperation dan competition. Analisis ini didasarkan pada logika yang mampu memaksimalkan kekuatan (strengths) dan peluang (opportunities), akan tetapi di saat yang sama dapat meminimalisir kelemahan (Weaknesses) dan ancaman (threats) yang dihadapi oleh perusahaan.

\section{Matriks QSPM}

Quantitative Strategic Planning Matric (QSPM) merupakan alat yang direkomendasikan oleh para ahli strategi untuk melakukan evaluasi dan guna memilih strategi alternatif secara objektif yang berdasarkan pada key success factor baik internal maupun eksternal yang telah diidentifikasikan sebelumnya. Secara konseptual, tujuan QSPM adalah untuk menetapkan kemenarikan relatif atas berbagai strategi yang bervariasi dalam rangka memilih strategi yang paling tepat dan sesuai untuk diterapkan (Umar, 2002).

\section{HASIL DAN PEMBAHASAN}

\section{Analisis Matriks IFE}

Berdasarkan hasil evaluasi terhadap faktor-faktor lingkungan internal pada Tabel 1, dapat diketahui bahwa reputasi sebagai produsen bibit tanaman dan buah stroberi khususnya di Jawa Barat, Indonesia merupakan kekuatan terbesar bagi CV. Bumi Agro Technology dengan nilai skor total sebesar 0.244 . Sementara faktor yang merupakan kelemahan terbesar bagi perusahaan adalah kapasitas produksi pada agribisnis stroberi $\mathrm{CV}$. Bumi Agrotechnology dan modal usaha perusahaan dengan skor total sebesar 0.084 .

Skor total perusahaan untuk faktor strategis internal sebesar 3.047 yang mengindikasikan bahwa CV. Bumi Agro Technology berada pada skor total di atas rata-rata 2.5 sehingga perusahaan dianggap dapat mengatasi kelemahan yang ada pada perusahaan dengan faktor kekuatan yang dimiliki perusahaan. 
Tabel 1. Hasil Evaluasi Faktor-faktor Strategis Internal CV. Bumi Agro Technology

\begin{tabular}{|c|c|c|c|c|}
\hline \multicolumn{2}{|r|}{ Faktor Strategi Internal } & $\begin{array}{l}\text { Rata-rata } \\
\text { Rating }\end{array}$ & $\begin{array}{l}\text { Rata-rata } \\
\text { Bobot }\end{array}$ & $\begin{array}{l}\text { Skor } \\
\text { Total }\end{array}$ \\
\hline \multicolumn{5}{|c|}{ KEKUATAN } \\
\hline A & $\begin{array}{l}\text { Memiliki visi dan misi yag spesifik terhadap } \\
\text { pengembangan agribisnis Stroberi }\end{array}$ & 3.17 & 0.066 & 0.208 \\
\hline $\mathrm{B}$ & Komitmen mengembangkan agribisnis Stroberi & 3.33 & 0.047 & 0.157 \\
\hline $\mathrm{C}$ & Kemampuan mengakses informasi dan peluang pasar & 3.50 & 0.064 & 0.224 \\
\hline $\mathrm{D}$ & Relasi yang luas (Networking) & 4.00 & 0.055 & 0.221 \\
\hline $\mathrm{E}$ & Kemampuan manajerial/operasional dalam organisasi & 2.83 & 0.049 & 0.140 \\
\hline $\mathrm{F}$ & Kualitas dan inovasi pada produk yang dihasilkan & 3.67 & 0.055 & 0.202 \\
\hline $\mathrm{G}$ & Kualitas pelayanan kepada konsumen & 3.67 & 0.050 & 0.183 \\
\hline I & Situasi dan lingkungan kerja yang kondusif & 3.00 & 0.046 & 0.139 \\
\hline \multicolumn{5}{|c|}{ KEKUATAN } \\
\hline $\mathrm{J}$ & $\begin{array}{l}\text { Reputasi sebagai produsen bibit tanaman dan buah stroberi } \\
\text { khususnya di Jawa Barat, Indonesia }\end{array}$ & 4.00 & 0.061 & 0.244 \\
\hline $\mathrm{K}$ & Koleksi tanaman stroberi yang dimiliki perusahaan & 3.83 & 0.061 & 0.235 \\
\hline $\mathrm{M}$ & Kegiatan penelitian dan pengembangan & 3.50 & 0.061 & 0.212 \\
\hline Q & Harga produk yang dijual oleh perusahaan & 3.17 & 0.051 & 0.161 \\
\hline \multicolumn{5}{|c|}{ KELEMAHAN } \\
\hline $\mathrm{H}$ & Kualitas komunikasi dalam organisasi di perusahaan & 2.67 & 0.048 & 0.129 \\
\hline $\mathrm{L}$ & Modal usaha perusahaan & 2.00 & 0.042 & 0.084 \\
\hline $\mathrm{N}$ & $\begin{array}{l}\text { Kapasitas produksi pada agribisnis stroberi CV. Bumi } \\
\text { Agrotechnology }\end{array}$ & 2.17 & 0.039 & 0.084 \\
\hline $\mathrm{O}$ & $\begin{array}{l}\text { Efektivitas pemasaran, pengiklanan dan promosi produk } \\
\text { dari agribisnis stroberi milik CV. Bumi Agrotechnology }\end{array}$ & 2.83 & 0.046 & 0.131 \\
\hline $\mathrm{P}$ & $\begin{array}{l}\text { Kualitas SDM (Sumber daya manusia) atau tenaga kerja } \\
\text { pada level teknis }\end{array}$ & 2.17 & 0.042 & 0.091 \\
\hline $\mathrm{R}$ & Upah Tenaga Kerja dan atau pemberian intensif & 2.33 & 0.047 & 0.110 \\
\hline $\mathrm{S}$ & Sistem pembukuan atau keuangan pada perusahaan & 1.33 & 0.069 & 0.092 \\
\hline \multicolumn{3}{|c|}{ Jumlah } & 1.000 & 3.047 \\
\hline
\end{tabular}

\section{Analisis Matriks EFE}

Berdasarkan hasil evaluasi terhadap faktor-faktor lingkungan eksternal pada Tabel 2, dapat diketahui sistem regulasi terkait agribisnis stroberi, sertifikasi dan perpajakan merupakan peluang terbesar bagi CV. Bumi Agro Technology dengan nilai skor total sebesar 0.210 . Sementara faktor yang merupakan ancaman terbesar bagi perusahaan adalah ancaman masuknya pendatang baru yang bergerak di bidang agribisnis stroberi dengan nilai skor total 0.244 .
Nilai skor total perusahaan untuk faktor strategis internal sebesar 2.469 yang mengindikasikan bahwa CV. Bumi Agro Technology berada pada skor total di bawah rata-rata 2.5 sehingga perusahaan dianggap belum dapat merespon peluang yang ada dan menanggapi serta mengantisipasi ancaman yang ada bagi perusahaan. 
Tabel 2. Hasil Evaluasi Faktor-faktor Strategis Eksternal CV. Bumi Agro Technology

\begin{tabular}{|c|c|c|c|c|}
\hline \multicolumn{2}{|r|}{ Faktor Strategi Eksternal } & $\begin{array}{l}\text { Rata-rata } \\
\text { Rating }\end{array}$ & $\begin{array}{l}\text { Rata-rata } \\
\text { Bobot }\end{array}$ & $\begin{array}{l}\text { Skor } \\
\text { Total }\end{array}$ \\
\hline \multicolumn{5}{|c|}{ PELUANG } \\
\hline $\mathrm{A}$ & Lingkungan usaha/pasar yang kondusif & 2.17 & 0.040 & 0.087 \\
\hline $\mathrm{B}$ & Permintaan pasar akan bibit tanaman stroberi & 1.00 & 0.035 & 0.035 \\
\hline $\mathrm{C}$ & Permintaan pasar akan produk buah stroberi & 2.00 & 0.041 & 0.082 \\
\hline $\mathrm{D}$ & Loyalitas konsumen pada perusahaan & 1.67 & 0.039 & 0.065 \\
\hline $\mathrm{G}$ & $\begin{array}{l}\text { Banyaknya agrowisata yang memanfaatkan budidaya stroberi } \\
\text { maupun produk stroberi }\end{array}$ & 2.17 & 0.051 & 0.111 \\
\hline $\mathrm{H}$ & $\begin{array}{l}\text { Kondisi Jawa Barat sebagai sentra budidaya stroberi di } \\
\text { Indonesia }\end{array}$ & 2.50 & 0.060 & 0.151 \\
\hline $\mathrm{J}$ & $\begin{array}{l}\text { Banyaknya petani mitra yang bekerja sama dengan CV. Bumi } \\
\text { Agrotechnology }\end{array}$ & 1.67 & 0.042 & 0.069 \\
\hline $\mathrm{K}$ & Sistem regulasi terkait agribisnis stroberi dan perpajakan & 3.33 & 0.063 & 0.210 \\
\hline $\mathrm{L}$ & Kemajuan dan inovasi teknologi yang dimiliki perusahaan & 1.00 & 0.046 & 0.046 \\
\hline $\mathrm{O}$ & $\begin{array}{l}\text { Banyaknya pemasok khususnya untuk input produksi bagi } \\
\text { agribisnis stroberi }\end{array}$ & 2.83 & 0.056 & 0.158 \\
\hline $\mathrm{P}$ & $\begin{array}{l}\text { Tanaman stroberi yang dibudidayakan yang sudah } \\
\text { tersertifikasi }\end{array}$ & 1.33 & 0.033 & 0.044 \\
\hline $\mathrm{R}$ & Terdapat banyak konsumen potensial & 1.17 & 0.042 & 0.049 \\
\hline $\mathrm{S}$ & Lokasi Perusahaan & 2.00 & 0.056 & 0.113 \\
\hline $\mathrm{T}$ & Keberadaan masyarakat sekitar di lingkungan perusahaan & 3.00 & 0.053 & 0.158 \\
\hline \multicolumn{5}{|c|}{ ANCAMAN } \\
\hline $\mathrm{E}$ & Kondisi perekonomian nasional saat ini & 3.17 & 0.044 & 0.141 \\
\hline $\mathrm{F}$ & $\begin{array}{l}\text { Isu pandemi Covid-19 bagi permintaan bibit dan buah } \\
\text { stroberi CV. Bumi Agrotechnology }\end{array}$ & 3.17 & 0.065 & 0.206 \\
\hline $\mathrm{I}$ & $\begin{array}{l}\text { Pesaing atau kompetitor agribisnis stroberi yang telah ada } \\
\text { sebelumnya }\end{array}$ & 3.50 & 0.069 & 0.243 \\
\hline M & $\begin{array}{l}\text { Ancaman masuknya pendatang baru yang bergerak di bidang } \\
\text { agribisnis stroberi }\end{array}$ & 4.00 & 0.061 & 0.244 \\
\hline $\mathrm{N}$ & $\begin{array}{l}\text { Banyak subtitusi buah stroberi dengan harga yang lebih } \\
\text { ekonomis dan mudah didapatkan di pasar }\end{array}$ & 2.67 & 0.051 & 0.136 \\
\hline $\mathrm{Q}$ & Kenaikan harga input produksi & 2.33 & 0.051 & 0.120 \\
\hline \multicolumn{3}{|c|}{ Jumlah } & 1.000 & 2.469 \\
\hline
\end{tabular}

Analisis Matriks IE

Berdasarkan hasil evaluasi faktor strategis internal dan eksternal menggunakan Matriks IFE dan EFE, diketahui bahwa skor tota faktor strategis internal CV. Bumi Agro Technology sebesar 3,047 dan skor total faktor strategis eksternal CV. Bumi Agro Technology sebesar 2,469.

Hasil skor total faktor strategis tersebut gabungkan dengan penempatan total skor faktor strategis internal dari matriks IFE pada sumbu $\mathrm{X}$ dan total skor faktor strategis eksternal pada sumbu Y.

Berdasarkan penggabungan seperti yang ada pada Gambar 3 tersebut diketahui bahwa posisi perusahaan berada pada sel IV. posisi perusahaan ada pada sel IV yakni tumbuh/kembangkan atau growth or build.

Adapun strategi yang dapat diterapkan ialah strategi intensif seperti 
penetrasi pasar, pengembangan pssar atau pengembangan produk dan strategi integrasi ke belakang, kedepan serta horizontal.

\begin{tabular}{|c|c|c|c|c|}
\hline \multicolumn{5}{|c|}{ Total Skor IFE $=\mathbf{3 . 0 4 7}$} \\
\hline \multirow{4}{*}{ 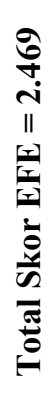 } & & $\begin{array}{l}\text { Tinggi } \\
3,0-4,0\end{array}$ & $\begin{array}{l}\text { Sedang } \\
2,0-2,99\end{array}$ & $\begin{array}{l}\text { Rendah } \\
1,0-1,99\end{array}$ \\
\hline & $\begin{array}{l}\text { Tinggi } \\
\mathbf{3 , 0 - 4 , 0}\end{array}$ & I & II & III \\
\hline & $\begin{array}{l}\text { Sedang } \\
2,0-2,99\end{array}$ & IV & $\mathrm{V}$ & VI \\
\hline & $\begin{array}{l}\text { Rendah } \\
1,0-1,99\end{array}$ & VII & VIII & IX \\
\hline
\end{tabular}

Gambar 3. Hasil Matriks Internal-Eksternal pada CV. Bumi Agro Technology

\section{Analisis SWOT}

Berdasarkan matriks IE, CV. Bumi Agro Technology berada pada posisi grow and built. Strategi yang diperoleh tersebut belum dapat diiplementasikan secara langsung pada perusahaan Berdasarkan posisi perusahaan pada matriks IE, strategi yang diperoleh dari matriks IE digunakan sebagai acuan untuk menentukan alternatif strategi bagi perusahaan untuk mengembangkan usahanya dengan posisi perusahannya.

Maka dari itu, pada matriks SWOT akan dirumuskan dengan jelas alternatif strategi bagi perusahaan berdasarkan faktor strategis internal dan eksternalnya.Berdasarkan hasil analisis
SWOT, diperoleh delapan strategi alternatif, antara lain:

1. Strategi Strengths-Opportunities (SO)

a. Mempertahankan kualitas produk yang dihasilkan dari tanaman stroberi yang dibudidayakan baik untuk produksi bibit dan buah stroberi. Dalam rangka memperoleh output produksi yang berkualitas secara kontinuitas, maka diperlukan input produksi yang berkualitas dan juga tepat guna. Input produksi yang berkualitas dapat berupa penggunaan bibit tanaman stroberi berkualitas dan bersertiifikat, tenaga kerja yang terampil, penerapan teknologi pada budidaya stroberi. Output produksi yang baik kualitas dan kuantitasnya tentunya dapat mempertahankan konsumen loyal yang selalu membeli bibit maupun buah stroberi dari CV. Bumi Agro Technology karena sudah terjamin kualitasnya.

b. Menciptakan varietas tanaman stroberi baru yang berkualitas serta meningkatkan jumlah varietas bibit stroberi bersertifikat. Strategi menciptakan varietas tanaman stroberi berkualitas serta 
meningkatkan jumlah tanaman stroberi bersertifikat merupakan pemanfaatan kekuatan CV. Bumi Agro Technology sebagai produsen bibit dan buah stroberi yang memiliki reputasi yang baik di Jawa Barat dan juga sebagai perusahaan yang memiliki tanaman stroberi bersertifikat di Indonesia yang legal untuk diperbanyak dan diperjual-belikan. Melalui strategi ini, dapat meningkatkan reputasi CV. Bumi Agro Technology dan dapat meningkatkan nilai jual produk di pasar karena kualitas dari produk yang sudah terjamin baik bahkan bersertifikat. Dalam jangka panjang juga strategi ini akan mempermudah perusahaan apabila ingin menjangkau pasar ekspor karena dari koleksi tanaman stroberi yang dibudidayakan sudah memiliki sertifikasi dan terjamin legalitas perusahaannya.

c. Pengembangan kemitraan antara perusahaan dengan konsumen maupun petani stroberi konvesional yang bermitra dengan CV. Bumi Agrotechnology untuk memperkuat usaha. Kemitraan yang dibentuk antara perusahaan dengan konsumen adalah guna menciptakan kepercayaan dan loyalitas konsumen terhadap perusahaan serta dapat membantu perusahaan untuk dipertemukan dengan konsumen potensialnya atas rekomendasi konsumen loyal perusahaan. kemitraan dengan petani stroberi konvensional dilakukan untuk mengatasi permasalahan modal dan keterbatasan kapasitas produksi. Kemitraan tersebut juga dapat meningkatkan kualitas dan kesejahteraan petani mitra, karena bibit tanaman stroberi berasal dari CV. Bumi Agro Technology. Dengan adanya petani mitra tersebut juga dapat membantu perusahaan ketika kekurangan jumlah produk untuk memenuhi permintaan konsumen dengan kualitas produk yang sama karena berasal dari bibit yang sama.

2. Strategi Strengths-Threats (ST)

a. Mempertahankan dan meningkatkan kualitas pelayanan kepada konsumen agar meningkatkan kepercayaan konsumen serta terus melakukan pembelian produk pada CV. Bumi Agrotechnology. Suatu organisasi 
pada perusahaan tidak hanya memerlukan struktur organisasi yang baik, visi dan misi perusahaan dan komitmen pengembangan usaha yang baik saja. Hal lain yang juga pentinng untuk dilakukan adalah mempertahankan dan meningkatkan kualitas pelayanan kepada konsumen. Salah satu cara yang dapa diakukan adalah dengan menjalin komunikasi yang baik agar konsumen mengetahui informasi mengenai produk yang dtawarkan, harga yang diberikan dan menjamin bahwa produk yang dihasilkan perusahaan berkualitas sehingga konsumen tetap percaya dan melakukan pembelian bibit maupun buah stroberi kepada $\mathrm{CV}$. Bumi Agro Technology di masa yang akan datang.

\section{Strategi Weaknesses-Opportunities} (WO)

a. Menambahan kegiatan pelatihan kerja untuk meningkatkan kualitas tenaga kerja atau SDM guna mengefektifkan penggunaan sumber daya yang dimiliki agar perusahaan memperoleh laba optimal. Strategi ini dilakukan dalam rangka mengptimalkan kapasitas produksi perusahaan. karena sumber daya manusia pada perusahaan merupakan faktor penggerak aktivitas produksi pada perusahaan. Sumber daya manusia yang berkualitas dan terampil tentunya dapat mengoperasikan teknologi yang diterapkan bagi perusahaan serta dalam rangka meningkatkan produktivitas tanaman stroberi pada perusahaan sehingga perusahaa dapat mencapai output yang sesuai target yang ditetapkan perusahaan. Kualitas dan keterampilan sumber daya manusia pada perusahaan dapat ditingkatkan melalui pelatihan kerja dan bimbingan langsung di lapangan selama kegiatan budidaya tanaman stroberi.

b. Memanfaatkan lahan kosong pada kebun guna menambah areal untuk mengoptimalkan kegiatan budidaya stroberi dalam rangka memproduksi bibit dan buah stroberi serta guna memenuhi permintaan pasar sehingga dapat meningkatkan laba bagi perusahaan. Strategi ini dilakukan untuk mengoptimalkan kapasitas produksi perusahaan dengan 
meningkatkan

efisiensi

penggunaan lahan yang kosong

yang dapat dialokasikan untuk

kegiatan budidaya stroberi pada

CV. Bumi Agro Technology sehingga dapat menghemat biaya untuk menambah lahan namun untuk investasi peralatan pertanian pada lahan kosong untuk meningkatkan produktivitas tanaman stroberi pada CV. Bumi Agro Technology.

\section{Strategi Weaknesses-Threats (WT)}

a. Meningkatkan kegiatan promosi dan pemasaran produk yang menarik sehingga perusahaan dapat memperoleh keuntungan yang optimal. Jawa Barat selain terkenal sebagai sentra produksi buah stroberi juga terkenal sebagai destinasi pariwisata yang banyak dikunjungi di Indonesia. Salah satu subsektor pariwisata adalah agrotourism ato agrowisata. Di Bandung banyak agrowisata kebun stroberi melihat dengan potensi dan kondisi alam di Jawa Barat yang sesuai untuk budidaya stroberi. Peningkatan agrowisata tersebut merupakan sumber konsumen potensial bagi $\mathrm{CV}$. Bumi Agro Technology.
Meskipun CV. Bumi Agro Technology memiliki reputasi sebagai bibit dan buah stroberi yang berkualitas dan bersertifikat, namun pada kenyataannya strategi promosi dan pemasaran yang dilakukan oleh perusahaan belum optimal dan masih belum dapat menjangkau konsumen potensial tersebut. Hal ini terlihat dari sering kali terjadi penjualan yang flukuatif. Selain itu, meskipun kapasitas produksi CV. Bumi Agro Technology terbatas, namun tak jarang terjadi dimana ketika perusahaan melakukan kegiatan produksi, namun permintaan yang ada sedikit bahkan ketika ada permintaan yang dibatalkan maka dapat memicu kelebihan stok bibit dan buah stroberi.

Menghadapi hal tersebut, maka perusahaan perlu mengantisipasi kelemahan dan ancaman yang dialami perusahaan dengan meningkatkan promosi untuk menjangkau konsumen potensialnya sehingga konsumen dapat mengetahui informasi mengenai produk yang ditawarkan oleh CV. Bumi Agro Technology dan tidak membeli 
produk dari produsen lain yang merupakan pesaing dari perusahaan. Selain itu, dengan promosi yang baik maka dapat meningkatkan permintaan terhadap produk sehingga tidak terjadi kelebihan produksi bagi perusahaan.

b. Memperbaiki sistem pembukuan dan keuangan pada perusahaan. CV. Bumi Agro Technology dalam mengurus keuangan, memantau cash flow pada perusahaan masih didasari pada pembukuan yang sangat sederahana dan pencatatan setiap pengeluaran dan penerimaan perusahaan masih disatukan menurut komoditas tanpa mengetahui pengeluaran dan penerimaan yang diperoleh pada tiap kebun-kebun produksi $\mathrm{CV}$. Bumi Agro Technology. Hal ini menyebabkan pihak manajemen perusahaan tidak mengetahui biaya produksi tiap kebun seperti apa padahal pada kenyataannya dari luas lahan setiap kebun dan produktivitas pada tiap kebun berbeda. Namun biaya produksi untuk tiap kebun dianggap sama rata.
Meskipun berdasarkan data analisis keuangan yang dilakukan oleh CV. Bumi Agro Technology, budidaya stroberi yang dilakukan masih menguntungkan dan layak untuk dilakukan perusahaan. Namun tidak jarang juga terjadi dimana ketika ada pengeluaran tidak terduga, atau biaya untuk produksi yang mendadak namun tidak dibeli dalam jumlah banyak pengeluaran tersebut tidak dicatatkan, sehingga keuntungan yang diperoleh perusahaan tidak optimal. Oleh sebab itu dengan strategi untuk memperbaiki pembukuan keuangan pada perusahaan pada tiap komoditas perkebun, sehingga dengan demikian dapat mengetahui produktivitas stroberi pada tiap kebun dan mengetahui biaya produksi yang diperlukan pada setiap kebun sehingga dapat meningkatkan efisiensi penggunaan modal yang terbatas juga namun tetap memberikan keuntungan yang optimal bagi perusahaan. 


\section{Analisis Matriks QSPM}

Prioritas strategi alternatif yang paling utama untuk diimplementasikan bagi perusahaan berdasarkan tabel hasil analisis matriks QSPM ialah strategi untuk mempertahankan kualitas produk yang dihasilkan dari tanaman stroberi yang dibudidayakan baik untuk produksi bibit dan buah stroberi dengan nilai TAS (Total Attractive Score) sebesar 4,368.

Tabel 6. Hasil Analisis Matriks QSPM pada CV. Bumi Agro Technology

\begin{tabular}{ccc}
\hline $\begin{array}{c}\text { Strategi } \\
\text { Alternatif }\end{array}$ & $\begin{array}{c}\text { Total Attractive } \\
\text { Score (TAS) }\end{array}$ & $\begin{array}{c}\text { Prioritas } \\
\text { Strategi }\end{array}$ \\
\hline Strategi 1 & 4.368 & I \\
Strategi 2 & 3.713 & IV \\
Strategi 3 & 3.475 & VII \\
Strategi 4 & 3.099 & VIII \\
Strategi 5 & 3.873 & II \\
Strategi 6 & 3.694 & V \\
Strategi 7 & 3.539 & VI \\
Strategi 8 & 3.755 & III \\
\hline
\end{tabular}

Strategi untuk mempertahankan kualitas produk tersebut menjadi hal yang penting melihat dengan kondisi dan situasi perusahaan saat ini. Berdasarkan penjelasan pihak manajemen CV. Bumi Agro Technology, dengan menerapkan strategi mempertahankan kualitas produk, maka perusahaan juga menjaga kepercayaan dan mempertahankan loyalitas konsumen terhadap produk $\mathrm{CV}$. Bumi Agro Technology. Melalui strategi tersebut, juga sebagai wujud komitmen perusahaan dalam pengembangan usaha serta guna mencapai misi perusahaan salah satunya ialah guna mengoptimalkan produksi.

\section{KESIMPULAN DAN SARAN}

\section{Kesimpulan}

Berdasarkan hasil pembahasan dan penelitian yang dilakukan pada $\mathrm{CV}$. Bumi Agro Technology, maka diperoleh kesimpulan sebagai berikut:

1. Reputasi sebagai produsen bibit tanaman dan buah stroberi merupakan faktor internal yang menjadi kekuatan utama, sedangkan faktor internal yang merupakan kelamahan utama bagi CV. Bumi Agro Technology adalah kapasitas produksi dan modal usaha perusahaan.

2. Faktor eksternal yang merupakan peluang utama bagi CV. Bumi Agro Technology adalah sistem regulasi terkait agribisnis stroberi, sertifikasi dan perpajakan. Sedangkan faktor eksternal yang merupakan ancaman terbesar bagi perusahaan adalah ancaman masuknya pendatang baru yang bergerak di bidang agribisnis stroberi

3. Berdasarkan hasil mastriks SWOT diperoleh delapan alternatif strategi yang kemudian dianalisis menggunakan QSPM, sehingga diperoleh urutan prioritas strategi sebagai berikut: (1) Mempertahankan 
kualitas produk, (2) Menambah

kegiatan pelatihan kerja,

Meningkatkan promosi,

Memperbaiki sistem pembukuan, (5)

Menciptakan varietas stroberi baru,

(6) Memanfaatkan lahan kosong pada

kebun produksi, (7) Mempertahankan

dan meningkatkan kualitas pelayanan

kepada konsumen dan

Pengembangan kemitraan antara

perusahaan dengan konsumen dan petani.

\section{Saran}

Berdasarkan hasil pembahasan dan penelitian yang telah disimpulkan di atas, maka terdapat beberapa hal yang dapat dijadikan saran bagi pengembangan agribisnis stroberi di CV. Bumi Agro Technology, antara lain:

1. Bagi CV. Bumi Agro Technology, sebagai produsen bibit dan buah stroberi yang memiliki reputasi baik khususnya di Jawa Barat, maka demi keberlanjutan produksi bibit dan buah yang berkualitas tentunya memerlukan input produksi yang berkualitas salah satunya adalah SDM (sumber daya manusia). SDM berkualitas dapat diperoleh baik merektrut tenaga kerja baru yang berkualitas maupun melalui peningkatan kualitas SDM yang sudah ada di perusahaan melalui penyuluhan, pelatihan rutin baik formal maupun non formal agar dapat meningkatkan kualitas SDM tersebut. Sehingga ketika akan melakukan penambahan penggunaan teknologi dapat mudah dioperasikan oleh SDM perusahaan. Dengan demikian, dapat meningkatkan produktivitas dan mengoptimalkan keuntungan bagi CV. Bumi Agro Technology.

2. Menambah jumlah varietas tanaman stroberi bersertifikat. Hal tersebut bertujuan untuk meningkatkan reputasi perusahaan dan dapat juga menjadi keunggulan kompetititif bagi CV. Bumi Agro Technology diantara para pesaingnya. Adanya penambahan varietas bersertifikat juga dapat mempengaruhi harga jual bibit dan buah stroberi yang dapat meningkat. Sehingga ada perbedaaan harga antara tanaman stroberi bersertifikat dengan yang belum bersertifikat.

\section{UCAPAN TERIMA KASIH}

Penulis mengucapkan terima kasih kepada pihak yang telah membantu dan mendukung pada penulisan jurnal ini yaitu Dr. Ir. Lucyana Trimo, MSIE., Diky Indrawibawa selaku pemilik dan direktur 
dari CV. Bumi Agro Technology, serta kedua orangtua yang sangat saya sayangi, Bapak, Lusia Silaban dan terutama untuk Mama, Harma Lisbeth Pakpahan yang sangat luar biasa selalu mendukung baik melalui materi, moral dan doa yang tidak pernah henti.

\section{DAFTAR PUSTAKA}

Budiman, S dan Saraswati, D. (2006). Berkebun Stroberi Secara Komersil. Penebar Swadaya. Jakarta.

David, F. R. (2009). Manajemen strategis konsep. Jakarta: Salemba Empat.

Kementerian Pertanian. (2015). Statistik Produksi Hortikultura Tahun 2014. Jakarta: Direktorat Jenderal Hortikultura

Purnomo, Febriano Setyawan Nur. (2008). Strategi Pengembangan Agribisnis Stroberi di Kabupaten Purbalingga. [Skripsi]. Surakarta: Universitas Sebelas Maret
Sahlan dan Sri Wahyuni. (2019). Strategi Pengembangan Agribisnis Strawberry (Fragaria vesca) di Desa Bonto Tallasa Kecamatan Ulu Ere Kabupaten Bantaeng. J-Pen Borneo: Junal Ilmu Pertanian eISSN No: 2599-2872, Vol 2, No. 2

Sopian, S.A., \& Trimo, L. (2020). Strategi Pengembangan Usahatani Bawang Putih di Kecamatan Ciwidey Kabupaten Bandung. Jurnal Pemikiran Masyarakat Ilmiah Berwawasan Agribisnis. Juli, 6(2), 794-802.

Sugiyono. (2006). Metode Penelitian Kuantitatif, Kualitatif, dan $R \& D$. Alfabeta.

Umar, H. (2008). Strategic Management in Action. Jakarta : PT Raja Grafindo

Sahlan dan Sri Wahyuni. (2019). Strategi Pengembangan Agribisnis Strawberry (Fragaria vesca) di Desa Bonto Tallasa Kecamatan Ulu Ere Kabupaten Bantaeng. J-Pen Borneo: Junal Ilmu Pertanian eISSN No: 2599-2872, 2(2). 